\title{
On the contribution of Iranian EFL teachers' sense of plausibility to language teaching pedagogy
}

\author{
Fahime Farjami ${ }^{1}$, Hanieh Davatgari Asl ${ }^{2}$, Ali Rezaee Javidan ${ }^{2}$ \\ ${ }^{1}$ Young Researchers and Elite Club, Ahar Branch, Islamic Azad University, Ahar, Iran \\ ${ }^{2}$ Department of English Language Teaching, Ahar Branch, Islamic Azad University, Ahar, Iran
}

\section{Email address:}

fahimefarjami@yahoo.com (F. Farjami), hdavatgar@yahoo.com (H. D. Asl), a.r.javidan@ gmail.com (A. R. Javidan)

\section{To cite this article:}

Fahime Farjami, Hanieh Davatgari Asl, Ali Rezaee Javidan. On the Contribution of Iranian EFL Teachers' Sense of Plausibility to Language Teaching Pedagogy. International Journal of Language and Linguistics. Special Issue: Foreign Language Teaching and Learning (Models and Beliefs). Vol. 2, No. 3-1, 2014, pp. 1-11. doi: 10.11648/j.ijll.s.2014020301.11

\begin{abstract}
The present study was conducted to investigate the impact of the teachers' sense of plausibility on their classroom practices. The participants were 42 male and female high school English teachers and some of their students. To fulfill the purpose of the study, a 60-item teacher's sense of plausibility questionnaire was administered to the teachers and a 29 item questionnaire was administered to their students to determine the effect of the teacher's sense of plausibility on the classroom performances. The analysis of data was done through Pearson Correlation and the parametric independent t-test analyses. The findings indicated that there is a close relationship between the teacher's sense of plausibility and his/her teaching performances. With respect to these findings, it could be concluded that the students whose teachers had a higher sense of plausibility had better language performances than those students whose teachers had a lower sense of plausibility which is worth considering.
\end{abstract}

Keywords: Sense of Plausibility, Self-Esteem, Teacher's Belief, Method, and Pedagogy

\section{Introduction}

Teacher's sense of plausibility as his/her awareness or pedagogic intuition of what constitutes the good teaching plays a key role in promoting the process of learning and setting optimal context for learning. Nowadays few teachers may search for the so-called best method; instead, effective teachers try to apply learning principles which are in harmony with their framework of set of beliefs and practices and the term method is best replaced by the term pedagogy. When the teacher's sense of plausibility is active, he/she can adapt resources, materials and methods to the learners' needs. Paying attention to what the teacher can control, his/her own interests in teaching and professional career, the preparation and adding variety to his/her practices as well as awareness of the principles of language teaching and learning can help the teacher to move beyond the nomothetic tradition i.e. having mechanical practices, to enjoy the hermeneutic tradition in which the teacher tries to have the subjective awareness of what he/she does in the classroom. In postmethod condition, the teacher and the learners act as co-explorers and the teacher functions as a practitioner according to his/her framework of growing set of beliefs and practices.
Teacher's sense of plausibility can potentially influence the various instructional practices which are applied in the classroom.

We want to show that failure and success of an educational enterprise depends on the teacher, it is the teacher who is often to blame for poor motivation or for fear of failure. Active sense of plausibility of the teacher signifies that the terminal objective of classroom practices is not how the teacher performs but the purpose is activating the students and involving them in the learning process. Effective teachers are plausible enough to control and manage the process of teaching, learning, and classroom interaction actively. This plausibility results from their understanding of the teaching and learning processes, and keeping up with the current research findings.

Through this study, we want to emphasize that in order to facilitate the process of learning, instead of looking at outside factors such as demographics, district leadership and so on, special focus should be on what the teacher can control; his/her own preparation, practices and principles of language learning teaching. 


\section{Sense of Plausibility in Postmethod Condition}

Kumaravadivelu (1994) identified what he called the "postmethod condition", a result of "the widespread dissatisfaction with the conventional concept of method"(p. 43).Rather than subscribe to a single set of procedures, postmethod teachers adapt their approach in accordance with local, contextual factors, while at the same time being guided by a number of "macrostrategies". Two types of these macrostrategies are: "Maximize learning opportunities" and "Promote learner autonomy". In 1990, Prabhu argued that "there is no one method but that individual teachers fashion an approach that accords uniquely with their sense of plausibility". As a teacher with active sense of plausibility, one can think in terms of a number of possible methodological options for tailoring classes to the particular context.

Teacher autonomy is another pedestal upon which the post method era stands. "The post-method condition; however, recognizes teacher's potentials: teachers know not only how to teach but also know how to act autonomously within the academic and administrative constraints imposed by institutions, curricula, and textbooks" (Kumaravadivelu, 1994, p.30).

A teacher's approach-with active sense of plausibility- to language teaching methodology is his/her theoretical rationale that underlies everything that she/ he does in the classroom. In stead of subscribing to a single set of procedures, postmethod teachers adapt their approach in accordance with local, contextual factors. We find it necessary to think of good teaching as an activity in which there is a sense of involvement by the teacher. When we encounter an instance of really bad teaching, it is most often not a case of the teacher following a method with which we disagree, but rather of the teacher merely going through the motions of teaching, with no sense of involvement, without evaluating understanding.

The conceptualization may arise from a number of different sources, including a teacher's experience in the past as a learner, a teacher's earlier experience of teaching, exposure to one or more methods while training as a teacher, what a teacher knows or thinks of other teachers' actions or opinions, and perhaps a teacher's experience as a parent or caretaker. Different sources may influence different teachers to different extents, and what looks like the same experience or exposure may influence different teachers differently.

The resulting concept or pedagogic intuition of how learning takes place and how teaching causes or supports it is what may be called a teacher's sense of plausibility about teaching. When a teacher's sense of plausibility is engaged in the teaching operation, the teacher can be said to be involved and the teaching can not be mechanical-each activity will be on the basis of the teacher's intuitions. Furthermore, when the sense of plausibility is engaged, the activity of teaching is productive; there is then a basis for the teacher to be satisfied or dissatisfied about the activity, and each instance of such satisfaction or dissatisfaction has itself a further influence on the sense of plausibility, confirming or disconfirming or revising it in some small measure, and generally contributing to its growth or change.

The question to ask about a teacher's sense of plausibility is not whether it implies a good or bad method but, more basically, whether it is active, alive, or operational enough to create a sense of involvement for both the teacher and the student. Mechanical teaching results from an overroutinisation of teaching activity, and teaching is subject to great pressures of routinisation. Teaching requires a certain degree of routine to make it sustainable or even endurable. An active sense of plausibility is very difficult to maintain among such pressures on routinisation, and can easily become frozen, ossified, or inaccessibly submerged, leaving only a schedule of routines.

When teachers profess to believe in some method they have been following, they may well be merely demonstrating how frozen their sense of plausibility is and, as a result, how insecure they feel against a threat to their teaching routines. When a teacher's sense of plausibility is active and engaged in teaching, it is necessarily open to change in the process of the ongoing activity of teaching. Such teaching can perhaps be regarded as being dynamic in contrast to teaching that is mechanical or static. We can then say that a distinction between dynamic and static teaching is more significant for pedagogy than any distinction between good and bad methods. According to Prabhu, the enemy of good teaching is not "a bad method, but overroutinisation".

Da Silva (2004) highlights that "the notion of teacher beliefs should be abandoned, in that it seems to entail a certainty on the part of the researcher as to exact underpinnings of the informants' professional convictions that is impossible to sustain" (p.168). He declares, "I would like to suggest that a teacher's sense of plausibility may be more productive" (p.168). He mentions that "the view that research in EFL/ESL is or should be problem-solving process that ideally provides solutions to the difficulties experienced by teachers and learners in the classroom. He uses exploratory practices-Allwright's (1999) frameworkfor teacher development and education which proposes the integration of teaching, learning, and research in a way that is relevant to all classroom participants. The exploratory teaching process moves beyond methods and focuses partly on exploring the nature of effective classroom teaching and learning.

\subsection{Teacher's Sense of Plausibility and the Dominant Philosophies of Learning}

Three dominant approaches to knowledge and learning will be briefly discussed, with a view to examining how each of them connects up the teacher's sense of plausibility to help learner autonomy. 


\subsection{Positivism}

Positivism is premised upon the assumption that "knowledge reflects objective reality. Therefore, if teachers can be said to hold this objective reality, learning can only consist of the transmission of knowledge from one individual to another" (Benson \& Voller, 1997, p. 20). Confirming this view is the maintenance and enhancement of the traditional classroom where teachers are the purveyors of knowledge and wielders of power, and learners are seen as "containers to be filled with the knowledge held by teachers" (ibid). Since it runs counter to the development of learner autonomy, the teacher's sense of plausibility is neglected and hidden.

\subsection{Constructivism}

In contrast to positivism, constructivism holds the view that rather than discovering objective knowledge (whatever that might mean), individuals recognize and restructure their experience. In Candy's term (Candy, 1991, p. 270), constructivism "leads directly to proposition that knowledge cannot be taught but only learned (that is, constructed)", because knowledge is something "built up by the learner" (von Glasserfeld \& Smock, 1974, cited in Candy, 1991, p.270 ). By the same token, language learning does not involve internalizing sets of rules, structures and forms; each learner brings her own experience and world knowledge to bear on the target language or task at hand. Apparently, "constructivism supports, and extends to cover psychological versions of autonomy that appertain to learners' behavior, attitudes, motivation, and self-concept" (Benson \& Voller, 1997: 23). As a result, constructivist approaches encourage and promote self-directed learning as a necessary condition for learner autonomy.

\subsection{Critical Theory}

This approach shares with constructivism the view that knowledge is constructed rather than discovered or learned. Moreover, it argues that knowledge does not reflect reality, but rather comprises "competing ideological versions of that reality expressing the interests of different social groups" (Benson \& Voller, 1997, p. 22). Within this approach, learning concerns issues of power and ideology and is seen as a process of interaction with social context, which can bring about social change. What is more, linguistic forms are bound up with the social meanings they convey, in so far as language is power, and vice versa.

Advocates of these movements see their mission as to convince teachers of the correctness of the theory, to review their teaching to see to what extend it matches their values, and to try to incorporate the relevant principles or values into their teaching. This approach focuses on teacher' set of beliefs and practices to provide a good framework for teaching and maximizing learning processes.
The interaction between one's approach and classroom practice is the key to dynamic teaching. Such issues lead us to postmethod pedagogy. In this approach the teacher as an autonomous individual whose active sense of plausibility urges him to foster learner autonomy.

\section{Recognition of the Essential Roles of the Teacher through Different Parameters}

Recognition of the essential roles of the teacher and the learner and of the need for situationally relevant language pedagogy has brought about the decline or demise of methods, with their specific philosophies and prescribed sets of classroom procedures. The 1990s witnessed new ideas that can fundamentally restructure second/foreign language teaching and education. Among them are two mutually informing currents of thought:

One emphasizes the need to go beyond the limitations of the concept of method with a call to find an alternative way of designing effective strategies (Clarke, 1994; Kumaravadivelu, 1994; Prabhu, 1990), and another emphasizes the need to go beyond the limitations of the transmission model of teacher education with a call to find an alternative way of creating efficient teaching professionals (Freeman \& Johnson, 1998; Johnson, 2000; Woods, 1996). The result has been a greater awareness of issues such as teacher beliefs, teacher reasoning, teacher cognition, and teacher's sense of plausibility.

Kumaravadivelu (2001/2003) declares particularity as one of the parameters of postmethod; it means that the sort of techniques teachers use depends on where, when and whom they are teaching. In fact, the situation determines how of teaching, yet the sociocultural and political issues affect the kind of teaching; therefore, the teachers should have a high understanding of the situation. By the notion of particularity, he suggests, "any language pedagogy, to be relevant must be sensitive to a particular group of teachers teaching a particular group of learners pursuing a particular set of goals within a particular institutional context embedded in particular sociocultural milieu." In other words, Prabhu (1990) stated that there should be a relationship between the teaching context and the applied methodology.

Another parameter mentioned by Kumaravadivelu (2001/2003) is practicality. By practicality he means that a method should be applicable in real situation; otherwise, the practice-theory relationship can not be approached; in other words, a theory is of no use unless it can be applied in practice. Thus, this characteristic motivates teachers to make theories from their practices and then practice what they have theorized .

The last parameter Kumaravadivelu (2001/2003) mentions is possibility, which means that the method should be appropriate socially, culturally, and politically. Because teachers and students attend the classroom with all 
their beliefs and thoughts and it cannot be stated that their personalities inside the classroom is separate from their personalities outside the classroom in their everyday lives. Giroux (1988, cited in Kumaravadivelu, 2001,) mentions that pedagogy of possibility points to "the need to develop theories, forms of knowledge, and social practices that work with experiences that people bring to the pedagogical setting"(p.543). Therefore, postmethod pedagogy demands a re-visioning of the teacher's role as a postmethod practitioner.

\section{The Post Method Teacher}

The postmethod teacher is an autonomous individual. When Kumaravadivelu (2003) talks about teacher's autonomy, he means that he/she should reach a specific degree of competence and confidence to build and implement their own theory of practice to do so; teachers should rely on their personal knowledge. Freeman (1996b) suggests that " personal knowledge does not simply entail behavioral knowledge of how to do particular things in the classroom; it involves a cognitive dimension that links thought with activity, centering on the context-embedded, interpretive of what to do" (cited in Kumaravadivelu, 2001, p. 549) and this is only possible when the teachers themselves want to acquire autonomy. Acquiring such autonomy requires formal and informal education, which should be a continual process. One way is performing a research: such a research is not a controlled experimental study, rather in such studies the teachers should concentrate on what they do with which group, why and how to do so. In fact it is a kind of action research( Kumaravadivelu, 2001).

Today, "language teaching is not easily categorized into methods and trends" (Brown, 2000,p.14). Instead, each teacher is called on to develop a sound overall approach to various language classrooms. This approach is a principled basis upon which the teacher can choose particular designs and techniques for teaching a foreign language in a particular context. There are no instant recipes. No quick and easy method is guaranteed to provide success. Every learner is unique, for example, some learner is visual, another is auditory, other is good at involving movement and the forth likes to negotiate. Every teacher is also unique; e.g., teachers' intuitions about the importance of repetition or meaningful input are not the same. Every learner-teacher relationship is unique as well, and every context is unique and teaching should be local, too.

The researcher believes that the active sense of plausibility of teacher leads him/her towards some principles on which classroom practice is grounded, the following set of principle is not static, it is a dynamic composite of activities and energies that changes or should change to create an appropriate atmosphere for effective learning:

\subsection{Principle of Encouragement}

It helps the teacher to create a classroom climate for language learning. The teacher influences the classroom environment by motivating unmotivated students.

\subsection{Principle of Independence}

Autonomous learning does not mean "unbridled learning". There should be a teacher who will adapt resources, materials and methods to the learners' needs.

\subsection{Principle of Self-Learning}

The focus is away from teaching and towards learning. The teacher should not neglect the teaching of how to learn. The more students understand the process of learning the foreign language, the more they will be able to take responsibility for their own learning.

\subsection{Principle of Innovation and Creation}

Creativity stimulates and motivates. Teachers who actively explore creative solutions tend to be more alive and vibrant than those who are content to follow a routine.

\subsection{Principle of Involvement/Activation}

Students are more likely to enjoy the subject, and to succeed in that, if they are involved in the learning process and, as far as possible, have to influence what happens, and how it happens.

\subsection{Principle of Planning}

It is the teacher's task to structure classroom activities. If the teacher has a woolly idea of what is required, the pace of the lesson will drop and students will become either bored or confused. Classroom instructions should be simple, precise, and explicit.

\subsection{Principle of Empowerment}

Freire (1970) states that students should be allowed to negotiate learning outcomes, to cooperate with teachers and other students in a process of discovery, to engage in critical thinking, and to relate everything they in school to their reality outside the classroom. Through empowering, the teacher helps learners to acquire the knowledge, skills, and strategies they will need in order to progress, to learn more, to tackle problems, and to meet new, emerging and unpredictable demands.

\subsection{Principle of Learning (Learning is More Important than Teaching)}

The important factor is that teaching is not the terminal objective of what takes place in the classroom. The important role of the teacher is that of catalyst; he/she helps learning happen through activating the students. 


\subsection{Principle of Cooperation/Collaboration}

It is a teacher's task to direct students to work cooperatively. When the teacher plans and executes, cooperative learning can lead to a more dynamic classroom interaction that promotes more learning.

\subsection{Principle of Cyclical Learning (Language Learning is Cyclical)}

Language learning is not linear; the same language item needs to be studied again and again throughout the course. The "repeats" within cyclical learning are not exact repeatseach repeat must be a development.

\subsection{Principle of Meaningful Learning Ways (Learners Learn in Ways That are Meaningful to Them)}

It is important that teachers realize the need to help learners to shape their learning strategies in ways that are meaningful to them, to encourage them to find their own style, to identify their own strengths, and to develop their own self-knowledge. The teacher needs to provide a variety of language learning activities.

The researcher tends to consider these principles in his research to find out that the Iranian English teacher's sense of plausibility is alive to ground the class room practices on the above-mentioned principles.

Regarding the above mentioned issues, the researcher would like to answer the following questions:

1. Is there a relationship between the teachers' sense of plausibility and their teaching performance?

2. Is there a significant difference between the language performances of the learners whose teachers have a higher sense of plausibility in comparison with the language performances of the learners whose teachers have a lower sense of plausibility?

\section{Method}

\subsection{Participants}

To carry out the purposes of this study, 42 male and female highschool teachers teaching English as an FL in Robat Karim and Parand of Tehran Province were studied. The second group of this study was some of the students of the above-mentioned teachers, the number of the students in these classes were 20 to 35 .

\subsection{Instrumentation}

The first instrument of this study was a standard questionnaire (see appendix A) which was administered to 42 male and female English teachers in the aforementioned towns. This questionnaire which is related to the teacher's sense of plausibility indicates their focus on the previously mentioned principles. To quantify the teacher's sense of plausibility, the researcher has to measure the amount of involvement of both the teacher and the student, the rate of teacher-learner rapport, and the scale of the teacher's familiarity with post modern approaches to teaching and learning; then if their rate is high, we can conclude that their sense of plausibility is alive. This questionnaire entails 60 items on a 5-point Likert scale ranging from 'strongly disagree'(1) to 'strongly agree'(5).

Another questionnaire (see appendix B) was applied. It was applied to study the effect of his/her alive sense of plausibility on the classroom practices for the students of the teachers with active sense of plausibility to show how the teacher's ongoing sense of plausibility will support learning and affect the classroom practices. It consisted of 29 items which had the numbers rating from 1 to 5.Each student would choose his/her answers that fitted with the experience of the teacher for each item In fact, this questionnaire is teacher evaluation by students; it consists of 15 items which deal with explicit curriculum-how well the teacher teaches the core subject. And there are 14 items which are about implicit curriculum-how well the teacher models the core values through how he/she behaves with the students.

\subsection{Procedure}

The following procedures were gone through to find convincing answer to the research question:

To conduct this study, the researcher asked all English teachers in Robatkarim and Parand to answer the questionnaire; however, forty-two of them took part in this research actively. After the data analysis, he went to their classes in order to have their students answer the related questionnaire.

The students would answer the questionnaire with 29 items. The researcher tried to study the effect of teacher's sense of plausibility on the classroom performances. We emphasize that a teacher's sense of plausibility does not deal with whether it implies a good or a bad method but, whether it is active, alive or operational to create a sense of involvement for both the teachers and the student. Therefore, the second stage would show whether both the English teacher and his/her students were involved in the learning processes.

\section{Investigation of the First Research Question}

The research data were collected through special questionnaires, as you can see (appendix A), through the related questionnaire, we could measure our colleagues' sense of plausibility. Then on the basis of student questionnaire (see appendix B), we got their students' answers and reactions to their teachers' senses of plausibility. The next phase of the research was to analyze those data. The process of data analysis began with analyzing plausibility statistics Table 1 and Table 2 below indicate the valid number of participants. 
Table 1. Plausibility Statistics.

\begin{tabular}{ccc}
\hline $\mathbf{N}$ & Valid Missing & $\mathbf{4 2 0}$ \\
\hline & Mean & 18.2202 \\
Median & 18.2950 \\
Mode & 20.00 \\
Std. Deviation & 1.32068 \\
Variance & 1.744 \\
Range & 4.73 \\
Minimum & 15.27 \\
Maximum & 20.00 \\
Sum & 765.25 \\
\hline
\end{tabular}

Table 2. Performance Statistics.

\begin{tabular}{ccc}
\hline $\mathbf{N}$ & Valid Missing & $\mathbf{4 2 0}$ \\
\hline & Mean & 13.7969 \\
Median & 13.3200 \\
Mode & $11.19^{\mathrm{a}}$ \\
Std. Deviation & 3.38077 \\
Variance & 11.430 \\
Range & 12.14 \\
Minimum & 7.86 \\
Maximum & 20.00 \\
Sum & 579.47 \\
\hline
\end{tabular}

The first research question sought to investigate the relationship between the teachers' sense of plausibility and their teaching performances. To answer this question a Pearson correlation analysis was run on the data available in table 1 and table2. Table 3 below indicates the results:

Table 3. Correlations.

\begin{tabular}{lccc}
\hline & & Plausibility & Performance \\
\hline \multirow{4}{*}{ Plausibility } & Pearson Correlation & 1 & $.710^{* *}$ \\
& Sig. (2-tailed) & & .000 \\
& $\mathrm{~N}$ & 42 & 42 \\
\multirow{3}{*}{ Performance } & Pearson Correlation & $.700^{* * *}$ & 1 \\
& Sig. (2-tailed) & .000 & \\
& $\mathrm{~N}$ & 42 & 42 \\
\hline
\end{tabular}

As indicated in table 3, a Pearson product moment correlation computed to assess the relationship between teacher's sense of plausibility and his/ her teaching performance. There was a significant positive correlation between the two variables $(r=.71, n=42, p<.05)$ it becomes clear that the null hypothesis, predicting no significant relationship between the teacher's sense of plausibility and his/her teaching performance is rejected.

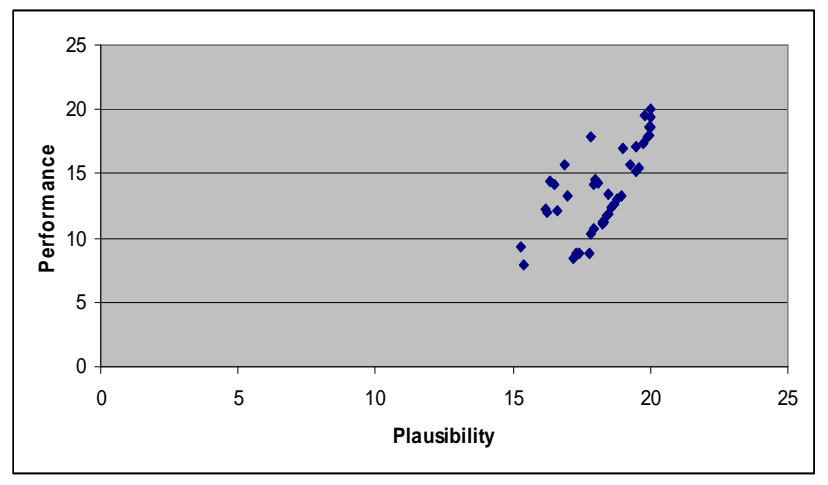

Graph 1

Meaningful clusters of dots imply correlations. This positive correlation indicates that as the teachers' sense of plausibility increase, so do their classroom performances.

\section{Investigation of the Second Research Question}

The second research question sought to investigate if there was a significant difference between the performance of the language learners whose teachers had a higher level of plausibility and those learners whose teachers had a lower level of plausibility. An independent t-test was run to compare the performance of the two groups of students (See appendix c). The group statistics are shown in Table 4.

Table 4. Group Statistics.

\begin{tabular}{lccccc}
\hline & groups & $\mathbf{N}$ & Mean & $\begin{array}{c}\text { Std. } \\
\text { Deviation }\end{array}$ & $\begin{array}{c}\text { Std. Error } \\
\text { Mean }\end{array}$ \\
\hline $\begin{array}{l}\text { High } \\
\text { plausibility }\end{array}$ & 1 & 30 & 17.3833 & 2.55705 & .46685 \\
$\begin{array}{l}\text { Low } \\
\text { plausibility }\end{array}$ & 2 & 30 & 15.4267 & 2.97592 & .54333 \\
\hline
\end{tabular}

As it is shown in Table 4, there was a significant difference in the scores of students whose teacher had a higher level of plausibility $(\mathrm{M}=17.38, \mathrm{SD}=2.55)$ and those learners whose teacher had a lower level of plausibility $(\mathrm{M}=15.42, \mathrm{SD}=2.97)$.

Table 5. Independent Samples Test.

\begin{tabular}{cccccccccc}
\hline & F & Sig. & t & df & Sig. (2-tailed) & Mean Difference & $\begin{array}{c}\text { Std. Error } \\
\text { Difference }\end{array}$ & $\begin{array}{c}\text { 95\% Confidence Interval } \\
\text { of the Difference } \\
\text { Lower } \\
\text { Upper }\end{array}$ \\
\hline $\begin{array}{c}\text { Equal variances } \\
\text { assumed }\end{array}$ & 300 & 586 & 2.731 & 58 & 008 & 1.95667 & 71635 & 52274 & 3.39059 \\
High & $\begin{array}{c}\text { Levene's } \\
\text { Test for } \\
\text { Equality of } \\
\text { Variances }\end{array}$ & $\begin{array}{c}\text { Equality of } \\
\text { Means }\end{array}$ & 2.731 & 56.715 & 008 & 1.95667 & 71635 & 52205 & 3.39128 \\
\hline
\end{tabular}


Table 4.9 provides enough criteria for the rejection of the second null hypothesis of this study(there are not any significant differences between the learners whose teachers have a higher sense of plausibility in comparison with the learners whose teachers have a lower sense of plausibility involved in teaching English in Iranian highschools ), because P-value which is . .008 is less than .05. So it shows significant difference. Furthermore the t-value observed which is 2.73 is more than the $\mathrm{t}$-value critical at the 0.05 level of significance. Therefore, we can safely claim that there is a significant difference between the performance of the learners whose teachers have a higher sense of plausibility in comparison with the learners whose teachers have a lower sense of plausibility.

\section{Discussion}

Based on the premise that "there is a factor more basic than the choice between methods, namely, the teacher's subjective understanding of the teaching they do" (Prabhu,1990) and that the teacher's sense of plausibility can help him/her to have better classroom practices, this study confirms Da Silva's notion that " a teacher's sense of plausibility may be more productive than teacher's belief". Since a teacher with active sense of plausibility acts as a practitioner or an explorer to improve his/ her teaching atmosphere and such a teacher looks for the best to improve learners' learning or autonomous learning.

This study is especially in line with William and Burden's (2000) hypothesis that " the best results are likely to occur when there is a combination of warm and supportive relationships, and a reasonably clear, orderly and well structured milieu". This notion was revealed through the study, and we showed that the teacher with active sense of plausibility tries to engage learners affectively and cognitively. Because a language classroom particularly needs to be a place where learners should be encouraged to use the new language to communicate, to negotiate, to make mistakes with no fear, and to learn from successes and failures. Affectively, a suitable environment for language learning should be one that enhances trust needed to communicate and which enhances learner's confidence and self-esteem.

\section{Conclusion}

The present study proves that first, Iranian EFL teachers with high senses of plausibility have better teaching performances and second, there is a significant difference between language performances of the learners whose teachers have a higher sense of plausibility in comparison with the learners whose teachers have a lower sense of plausibility. Language teachers must become aware of the gap between teaching practices with high sense of plausibility in comparison with low sense of plausibility.

As there is not a comprehensive method to be applied to promote teaching English as an Fl, the active sense of plausibility can drive the teacher's instructions in his/her classroom practices; rather than looking for magic method, the teacher works at the level of principle which is his/ her dynamic activities. In this way the interaction between the teacher's sense of plausibility and his/her classroom practices is the key to dynamic teaching, and we can evaluate a good teaching or teaching performance in terms of how the students learn and how the teacher helps to make learning happen through activating and involving them affectively and cognitively-the more the learners feel involved in the process of learning, the more successful and enjoyable they will find it to learn. Therefore, it is necessary for teachers to keep their sense of plausibility alive to keep up with dynamic teaching. 


\section{Appendix}

\section{باسمه تعلئى}

با سلام

همكار كر امى برسشنامه ى زير به منظور ارتقاى كيفيت آموزش زبان انغليسى در دبيرستان تهيه كرديده و

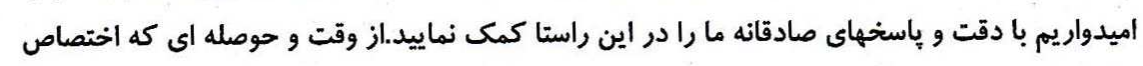

منسيت: مريد بسيار متشكريم.

\begin{tabular}{|c|c|c|c|c|c|c|}
\hline كخالفم & 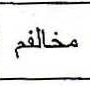 & نظارى & مو افقم & كوامقا & & \\
\hline & & & & & معلم بايد نكته ى درست را به دانش اموز ار ائه دهد. & 1 \\
\hline & & & & & معلم بايستى در كار حرفه خود مستقل باثند. & r \\
\hline & & & & & معلم بايستى مشوق دانش اموز ان در كلاس باثثد. & $r$ \\
\hline & & & & & معلم بايستى فعاليتهاى كلاسى متتوعى داشته باشد. & 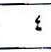 \\
\hline & & & & & معلم بايستى زمينه اي فر اهم كند كه دانش آموزان خودشان ياد بكِيرند. & $\circ$ \\
\hline . & & & & & 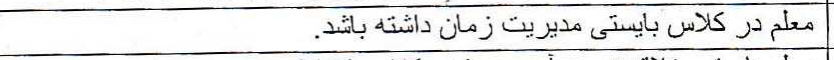 & 1 \\
\hline & & & & & معلم بايستى خلاقيت و نو آورى ر ا در كلاس افز ايش دهد. & $\mathrm{v}$ \\
\hline & & & & & معلم نبايد باعث شر مسارى دانش اموز ان شود. . & $\wedge$ \\
\hline & & & & & معلم بايد در تصميم كبرى هاى اموزشى نش اينا كند. . & 9 \\
\hline & & & & & 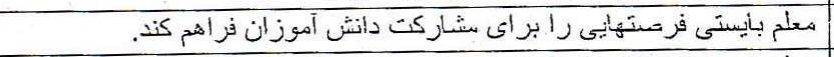 & $i$ \\
\hline r & & & & & معلم بايد به كار خود علاقه مند باتش. & 11 \\
\hline & & & & & معلم بايستى به دانش اموز ان بازخورد سازنده و مثبت ارائه دهد. & ir \\
\hline & & & & & معلم بايستى با مسئوليتهاى آموزشى خود آشنا شود. . & ir \\
\hline & & & & & معلم در كار حرفه الى خود بايستى با انكَيزه باشد. & $1 \leqslant$ \\
\hline & & & & & معلم بايستى حمايت كِر دانش اموز ان باتثد. & 10 \\
\hline & & & & & معلم بايستى در كار خودش نظم داشته باتشد. & 17 \\
\hline & & & 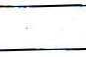 & & معلم بايستى از روش اثر بخشى در كلاس درس استفاده نمايد. & iv \\
\hline & & & & & شود. مبلم بايستى كمى كند تا محتو إى درسى با تجربه فردى دانش آموزان هم كام & 11 \\
\hline & & & & & معلم بايستى با دانش اموز ان ارنباط عاطفي برقرار كند. & 19 \\
\hline & & & & & معلم بايد در موضوع درسى خود اكَاهى بالاِيى داشته باشند. & $r \cdot$ \\
\hline & & & & & معلم بايستى دانش آموز ان را بار اهبر دهاى يادكيرى(استر اتزّى) اشنا كند. & Y1 \\
\hline & & & & & معلم بايسنى از نظر اجتماعى احساس مسنوليت كند. . & rr \\
\hline & & & & & معلم بايستى از تكنيك هاى كار امد در تدريس خود استفاده نمايد. & $r$ \\
\hline & & & & & معلم بايستى هميارى و مشاركت دانش آموزان را افز ايش دهد. & $r \leqslant$ \\
\hline & & & & & معلم بايد از ارزشبابى تكوينى استفاده نمايد. & ro \\
\hline & & & & & در اداره كلاس، معلم بايستى مدير خوبى باثد. & YY \\
\hline & & & & & معلم بايستى با ادب وفروتن باثد. & rv \\
\hline & & & & & معلم بايستى نكاليف دانش اموز ان را به طورمنظم كنترل كند. & rA \\
\hline & & & & & معلم بايستى در ار ايه مطالب درسى تداوم و ثُبات نشان دهد. & ra \\
\hline & & & & & معلم بايستى برروى فر ايند بادكيرى تامل با باز انديشى داشته باشد. & $r$. \\
\hline
\end{tabular}

A. Used Teacher's Questionnaire. 


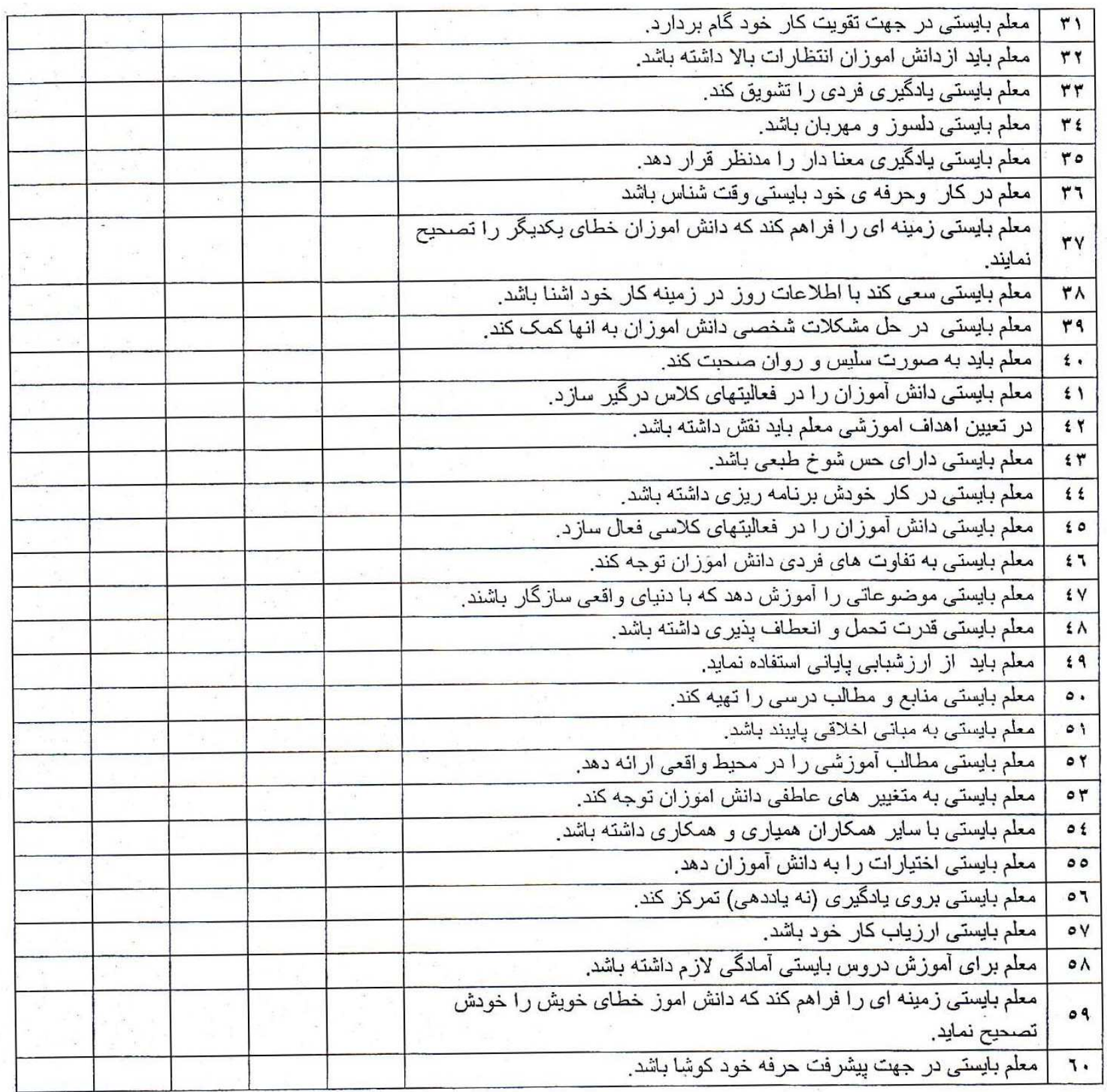

B. Student questionnaire.

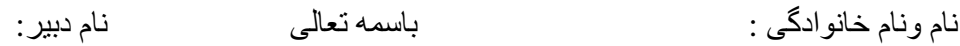

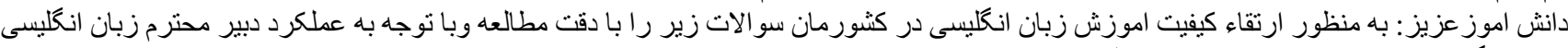

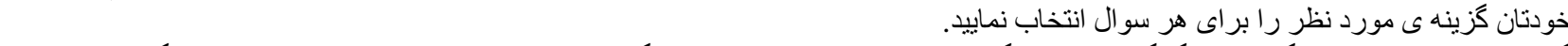

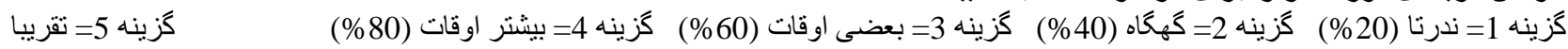
هميثه (100\%) $\begin{array}{lllll}1 & 2 & 3 & 4 & 5\end{array}$
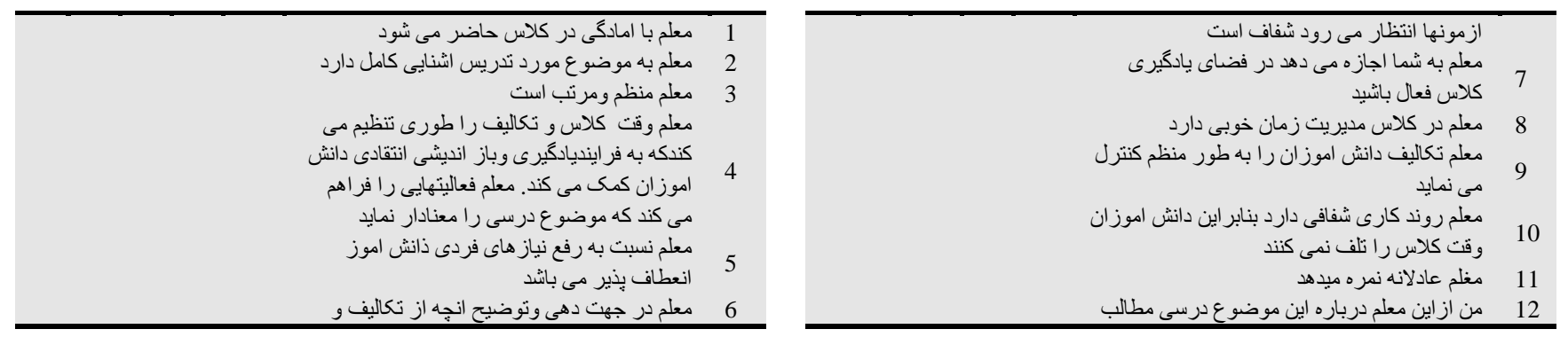


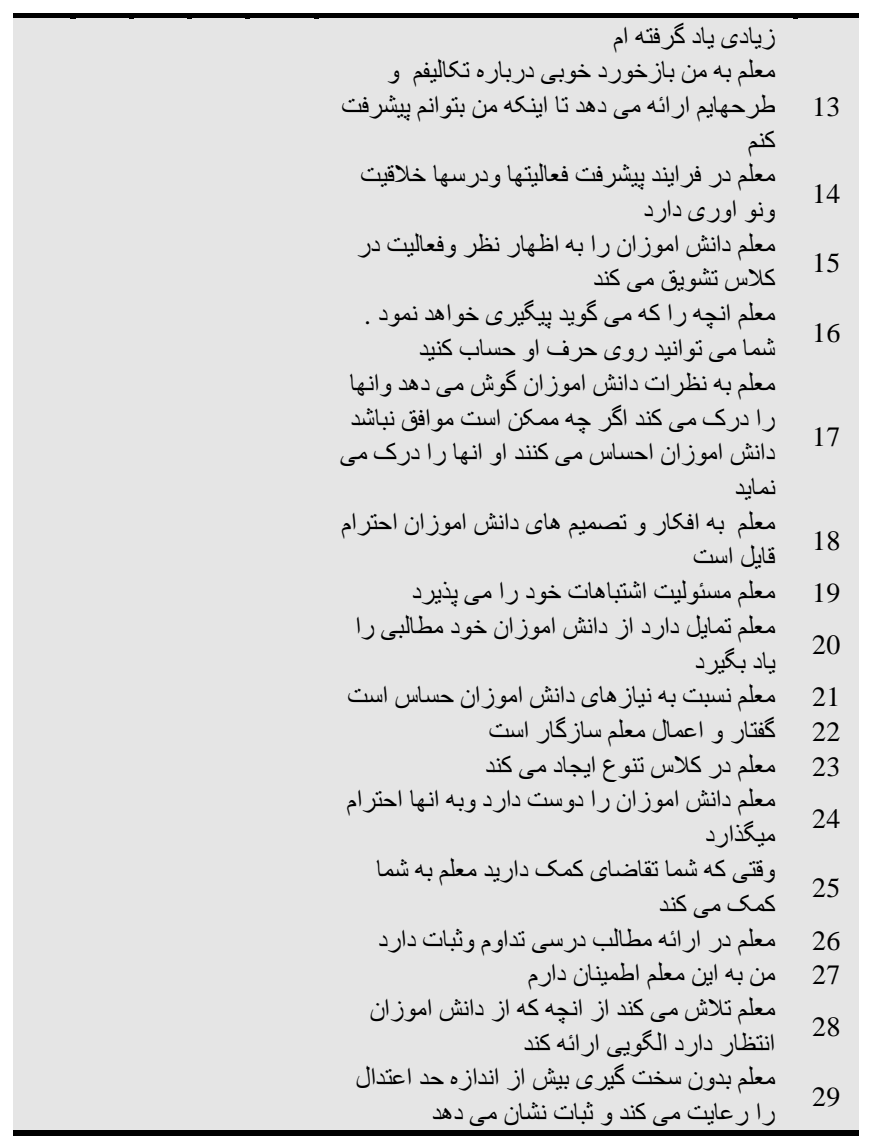

C. Comparison-T test-Hypothesis 2.

Teacher A with low sense of plausibility= 13.93

The students' marks (performance) for teacher A:

\begin{tabular}{ll}
\hline 1. & 8.55 \\
2. & 8.82 \\
3. & 9.5 \\
4. & 10.75 \\
5. & 12 \\
6. & 12.82 \\
7. & 13.10 \\
8. & 13.10 \\
9. & 14.62 \\
10. & 17.7 \\
11. & 15.7 \\
12. & 15.80 \\
13. & 15.80 \\
14. & 16 \\
15. & 16 \\
16. & 16.36 \\
17. & 16.55 \\
18. & 16.60 \\
19. & 16.68 \\
20. & 17.10 \\
21. & 17.24 \\
22. & 17.37 \\
23. & 17.65 \\
24. & 17.65 \\
25. & 17.93 \\
\hline
\end{tabular}

\begin{tabular}{ll}
\hline 26. & 17.93 \\
27. & 18 \\
28. & 18. \\
29. & 18.48 \\
30. & 19 \\
\hline
\end{tabular}

Teacher B with high sense of plausibility=20

The students' marks (performance) for teacher B:

\begin{tabular}{ll}
\hline 1. & 11.86 \\
2. & 12.27 \\
3. & 12.96 \\
4. & 14 \\
5. & 14 \\
6. & 14.62 \\
7. & 14.85 \\
8. & 15.58 \\
9. & 16.11 \\
10. & 16.27 \\
11. & 16.82 \\
12. & 17.10 \\
13. & 17.24 \\
14. & 17.90 \\
15. & 18 \\
16. & 18.20 \\
17. & 18.62 \\
18. & 18.89 \\
19. & 19 \\
20. & 19.31 \\
21. & 19.44 \\
22. & 19.44 \\
23. & 19.58 \\
24. & 19.58 \\
25. & 19.86 \\
26. & 20 \\
\hline
\end{tabular}

\section{References}

[1] Akbari, R.(2008) Postmethod discourse and practice. TESOL Quarterly. 42/2.

[2] Alemi, M. \& Daftarifard. P. (2010). Pedagogical Innovations in language teaching methodologies. Academy Publisher. 1, 6, 765-770.

[3] Barg, S.(2003). Teacher cognition in language teaching. Lang. teach. 36, 81-109.

[4] Benson. P. \& Voller, P (1997). Autonomy and Independence in language learning. London; Longman.

[5] Brown, H. D.(2000). Principles of Language Learning and Teaching. A Pearson Education Company. 
[6] Candy, (1991). Self-direction for lifelong learning. California: Jossey.

[7] Da Silva, C. P. (2004). Teachers and Learners: Investigating the language classroom. TESOL Quartly, 17, 3, 163-176.

[8] Doff, A. (1990). Teach English. Cambridge University Press.

[9] Garter, R. \& Nunan, D. (2001). Teaching English to speakers other of Languages. Cambridge university press.

[10] Gatbonton, E. (2008). Looking beyond teacher's Classroom Behavior: Novice And Experienced ESL teacher's pedagogical knowledge. LTR, 161-182.

[11] Hargreaves, A. (1994). Changing teachers, changing times. New York: Teacher College.

[12] Hinkel, E. (2006). Current perspectives on teaching the four skills. TESOLQuarterly. 40, 1, 109-131.

[13] Jia, Y, Eslami, Z, R. \&Burlbaw, I. (2006). ESL teachers' perceptions and factors

[14] Influencing their use of classroom- based reading assessment. Bilingual Re-Search Journal. 29(2), 459-482.

[15] Kumaravadivelu, B.(1994). The Post method condition : (E)merging strategies for second/ foreign language teaching. TESOL Quarterly .28

[16] Kumaravadivelu, B. (2001). Toward a post method Pedagogy. TESOL

[17] Quarterly, 35(4), 537-560.

[18] Kumaravadivelu, B, (2003). Ten Macro strategies for teaching language.

[19] Yale university press.

[20] Lewis, M. \& Hill, J.( 1990). Practical techniques for language teaching.

[21] Commercial color press, London.

[22] Micheslo, w. \& Harvey, A. S. (2000). Is teacher's work never done? Time-use and subjective outcomes. ICAAP. 1-8.

[23] Nation, I.S.P \& Macalister, J(2010). Language Curriculum Design. Rutledge: New York.

[24] Nunan, D.(1993). Syllabus Design. Oxford University Press.
[25] Nunan, D.(2000). Second Language Teaching and Learning. USA: Heinle \& Heinle.

[26] O'Malley, J.M and Chamot, A.U (1990). Learning strategy in Second Language Acquisition. Cambridge University Press.

[27] Pallant, J.(2007). SPSS-Survival Manual . Open University Press.

[28] Parajes, M.F(1998). Teachers' beliefs and Educational Research: Cleaning up a Messy Construct. Review of Educational Research 62(3), 307-332.

[29] Pennycook, A. (1989). The concept of method, Interested knowledge, and the Politics of language teaching. TESOL Quarterly. 23, 4, 589-613.

[30] Prabhu, N. S. (1990). There is no best method-why? TESOL Quartly, 24, 2, 161-176.

[31] Prabhu, N.S. (1987). Second Language Pedagogy. Oxford University press.

[32] Prabhu, N,S. (1992). The dynamics of the language lesson. TESOL

[33] Richards, J. C. \& Renandya, W. A. (2002). Methodology in language Teaching. Cambridge university press.

[34] Salmani, M. A. (2006). Language teaching: State of the art. The reading matrix, 6,2, 125-137.

[35] Schmitt, N. (2002). Applied Linguistics. Arnold, New York

[36] Spratt, M.(1999). How good are we at knowing what learners like? System, 27, 141-155.

[37] Stern, H.H(1991). Fundamental concept of language teaching. Oxford University Press.

[38] Thanasoulas, S. (2011). What is learner autonomy \& how can it be fostered? Internet TESOL journal. 1-12.

[39] Ur, $\mathrm{P}(1996)$. A Course in Language Teaching: Practice and Theory. Cambridge Cambridge University Press.

[40] Wenden, A. L. (1985). Learner Strategies. TESOL Newsletter, 19, 1-17.

[41] Williams, M. \& Burden, R. L.(2000). Psychology For Language Learning. Cambridge University press. 